\title{
Pastoral aquaculture in the reservoirs of the Kuban basin
}

\author{
Alexey Abramchuk ${ }^{1, *}$, Georgy Moskul ${ }^{1}$, Natalia Pashinova $^{1}$, Natalia Yurina $^{2,3}$ and Denis \\ Yurin $^{2}$ \\ ${ }^{1}$ Kuban state University, 149, Stavropol str., 350040, Krasnodar, Russia \\ ${ }^{2}$ Krasnodar scientific center for animal science and veterinary medicine, 4, Pervomayskaya str., \\ Znamensky village, 350055, Krasnodar, Russia \\ ${ }^{3}$ Kuban state agrarian University named after I. T. Trubilin, 13, Kalinin street, 350044, Krasnodar, \\ Russia
}

\begin{abstract}
The article provides calculations and recommendations for fisheries development and improvement of fish productivity of reservoirs in the Kuban basin. The taxonomic composition of water biological resources has been studied and the natural bio-production potential of some reservoirs in the South of Russia has been determined. It is proposed for the purpose of pastoral aquaculture to produce directed formation of the ichthyofauna of reservoirs by yearlings Hypophthalmichthys molitrix, Hypophthalmichthys nobilis, Ctenopharyngodon idella, and as anaddition Cyprinus carpio, Mylopharyngodon piceus, Liza haematocheila with an individual mass not less than 25-30 g, which will allow rational use of forage resources of aquatic ecosystems.
\end{abstract}

\section{Introduction}

In the Kuban basin, there are more than 15 reservoirs located on the territory of four southern regions of the Russian Federation: the Karachay-Cherkess Republic, Stavropol territory, Krasnodar territory and the Republic of Adygea.

In the Krasnodar territory there are 3 reservoirs with a total area of 47.9 thousand ha, including Krasnodar area of 40 thousand hectares - pond two regions (Krasnodar Krai and Adygeya Republic); Kryukovskaya area of 4 hectares and Varnavinsky - 3,9 thousand hectares of the Reservoir, as pasture reservoirs are operated very inefficiently. In recent years, the catch in reservoirs has decreased by 5.6 times compared to the beginning of the 90 - ies of the last century, while herbivorous species that make up more than $65 \%$ of the catches have not been found in catches since 2001. Currently, the fishery is based mainly on low-value fish species (Pelecus cultratus, Carassius auratus, Rutilus rutilus, Blicca bjoerkna, etc.). The reasons for the inefficient use of reservoirs as pasture reservoirs are insufficient volumes of stocking them with fish-planting material of herbivorous species, low efficiency of fishing, as well as unrecorded catch.

\footnotetext{
* Corresponding author: apilab@yandex.ru
} 


\section{Brief description of reservoirs in the Kuban basin}

Krasnodar reservoir. Intensive development of the national economy and expansion of areas for irrigated agriculture caused the need to create a Krasnodar reservoir on the Kuban river in the Krasnodar region.

Commissioned in 1975, this artificial reservoir is the largest integrated irrigation facility in the North Caucasus. Along with the tasks of eliminating catastrophic floods on the Kuban river and tributaries, releasing water to rice systems, providing for the needs of navigation and water supply, this reservoir is designed to solve a number of fisheries problems. These include the provision of water for desalination fish-reclamation systems, maintenance of spawning and growing farms near the village of Ryazan and Krasnodar sturgeon-rybtsovo-shemayny plant, and fishing releases to natural spawning grounds. With the commissioning of the Krasnodar reservoir, there are great opportunities for rational use of the reservoir to obtain valuable fish products and sell them fresh to the urban population.

As you know, the fishery in the reservoir is created anew, starting from the first and most important link-the formation of the raw material base of the fishery, i.e. fish stocks and feed resources for them. Solving these issues requires comprehensive research from the first days of the reservoir. The study of the biological regime of the reservoir will allow to form the fauna of fish and feed invertebrates in a targeted way.

The reservoir has the following design parameters (for NPS): the volume of 2350 million $\mathrm{m}^{3}$, the mirror area- $402 \mathrm{~km}^{2}$, the average depth-5.85 m, the maximum length and width-46 and $20 \mathrm{~km}$.

The thermal regime of the reservoir is characterized by minimum temperatures in January-February $\left(0.2-0.6^{\circ} \mathrm{C}\right)$ and maximum $\left(26-28^{\circ} \mathrm{C}\right)$ in July-August. Water belongs to the type I bicarbonate-calcium group with a total mineralization from 249 to $506 \mathrm{mg} / 1$. the Content of biogenic elements varies: phosphates - from 0.01 (in spring and autumn) to 0.18 $\mathrm{mg} / \mathrm{l}$ (in summer), nitrates - from 1.18 (in spring and autumn) to $0.3 \mathrm{mg} / \mathrm{l}$ (in summer).

According to morphological, hydrological and hydrochemical features, the water area of the reservoir can be divided into a number of sections:

1. The upper section of the reservoir, in the redevelopment of the area, the depth is from 3 to $5 \mathrm{~m}$. the site Mode has transitional features from the channel to the standing reservoir mode.

2. The Central part of the reservoir; its width reaches $15 \mathrm{~km}$, with depths from 5 to $8 \mathrm{~m}$. the river regime Prevails with sections of a standing reservoir.

3. The lower part of the reservoir (near-dam zone) has typical features of a sump, with a depth of 8 to $12 \mathrm{~m}$ and a width of $15 \mathrm{~km}$.

4. The river section (flooded riverbeds of Kuban, Psekupsa, przysz, Belaya) is the smallest in area, with a river regime, with a significant flow rate and turbidity.

Kryukov reservoir was built in 1972 in the vicinity of the village of Lviv on the site of the former Kryukov estuary. Putting it into operation allows you to significantly regulate the flood activity of the system of mountain rivers: Il, gerbanka, Bugay, Dry khable, Akhtyr, Zybza and Bugundyr. Directly in the reservoir fall river: or, gerbil, bull and Sabsa. The flow of other rivers is intercepted by the upland channel and sent to the reservoir. The volume of the Kryukov reservoir is estimated at over 110 million $\mathrm{m}^{3}$ of water, and the water mirror area is about 4 thousand hectares. This reservoir is a relatively shallow artificial reservoir, its average depth does not exceed $3.15 \mathrm{~m}$.the level of filling of the reservoir depends on the high water of the rivers. They are especially rich in water during the melting of snow and heavy rains. To the largest and most full-flowing rivers are: Il, Dry Jable Akhtyr'.

The water of the Kryukov reservoir belongs to the second type of bicarbonate-calcium group with mineralization from 0.33 to $0.49 \mathrm{mg} / 1$. the total nitrogen Content ranges from 


\subsection{3 to $2.65 \mathrm{mg} / 1$, phosphorus- $0.15-0.34 \mathrm{mg} / \mathrm{l}$.}

The varnavinskoye reservoir was created in 1971 on the Varnavinskiye plavniks, located in the left-Bank floodplain of the Kuban river, $10 \mathrm{~km}$ North-East of Krymsk, Krasnodar territory. The area of the reservoir at the NPU is 3900 ha, the volume is 40 million $\mathrm{m}^{3}$.

Of many rivers (Abin, Second, Adagum, And Heceptin, Khobza, Kudako, Nepal, Psif, Sebas, Schuch), conditionally related to the river system, Varnavinsky reservoir, reservoir flow Abin, And, Second, the Adagum. The Abin river is the largest and most water - rich: its length is $81 \mathrm{~km}$, its catchment area is $450 \mathrm{~km} 2$, and the average long-term annual flow is 207 million L3. The other rivers are much smaller. The water resources of the rivers of the Varnavinsky reservoir system are used mainly for agricultural purposes, they are included in the Varnavinsky and Fedorovsky rice systems. The water of the Varnavinsky reservoir belongs to the second type of hydrocarbonate-calcium group (mineralization-0.44-0.65 g / 1, hardness-4.40-6.68 mg-EQ/1, alkalinity-3.25-4.58 mg-EQ/1).

The main ions are NSOs- and $\mathrm{Ca} 2+$, which determine the carbonate equilibrium. Active reaction of water $\mathrm{pH}$ of $7,5-8,6$. The content of biogenic elements varies: nitrogen-1.34$1.91 \mathrm{mg} / 1$, phosphorus-0.12-0.36 mg / 1 .

Thus, the hydrological and hydrochemical regimes of reservoirs in the Kuban basin are generally satisfactory and do not interfere with pastoral fish farming.

\section{Hydrobiological regime of reservoirs in the Kuban basin}

Krasnodar reservoir. Phytoplankton. Phytoplankton of the reservoir is represented by 205 species of algae belonging to 9 groups: protococcocci (Protococcophyceae), diatomeae (Diatomeae), blue-green (Cyanobacteria), volvocaceae (Volvocaceae), desmidiales (Desmidiales), euglenoidea (euglenoidea), pyrophyta (Pyrrophyta), yellow-green (Xanthophyta), Golden (chrysophyta). The species diversity is dominated by Protococcophyceae (75 species) and Cyanobacteria (41 species) algae. Diatomeae (32 species) and Euglenoidea (26 species) are fairly well represented, accounting for 32 and 26 taxa, respectively. Other groups of algae include from I to 10 species.

The predominant development of algae was observed in coastal shallow, well-warmed areas of the reservoir. In deeper areas, in former riverbeds (Laba, Belaya, Pshish, Marta, Psekups), their species composition is much poorer [1,2,3,4].

The microflora of the Krasnodar reservoir is characterized by seasonal dynamics, and there is a direct dependence of population accumulation on water temperature. The correlation coefficient is 0.701 .

In winter, environmental conditions, especially low water temperatures and short daylight hours, determine the small number of phytoplankton, which is about $3.1 \%$ of the annual amount. In the following months, there is an increase in the mass of algae, reaching the highest number in July $-42.9 \%$, then there is a gradual decrease in the number.

In winter and in the early spring, diatomeae (Diatomeae) prevail among the microalgae of the reservoir in terms of number and biomass. Mass development at this time is achieved by representatives of the genera Cyclotella, Melosira, and Naricula. Protococcal (Protococcophyceae), blue-green (Cyanobacteria), euglenic (Euglenoidea), volvocaceae and other groups of microflora in winter plankton are very poorly represented.

The value of Protococcophyceae in the reservoir increases from winter to autumn. During the year, they are represented by small forms of the genus Chlorella, Ankistrodesinus, their number is significant-50-5208 thousand copies $/ \mathrm{m}^{3}$, but their primary role in plankton is periodically obscured by the predominance of Cyanobacteria (the most widespread of them are Merismopedia punctata, Anabaenopsis Elenkinii, Oscillatoria limnetica).

The horizontal distribution of phytoplanktin in the reservoir is uneven, the most 
productive microflora is the dam site and the left-Bank shallow zone between the mouths of rivers such as Psekups and przysz.

The tiered distribution of the taxonomic composition and biomass of lower algae also has certain regularities. Lowering the water temperature and reducing the amount of sunlight with increasing depth, make the environment for these organisms less attractive. As a rule, with increasing depth, the biomass and number of suspended plant organisms decreases, and the taxonomic composition becomes much poorer. The most preferred for the development of phytoplankton is the upper part $(0.5 \mathrm{~m})$ of the water column of the reservoir, at a depth of about 2 meters, its biomass is reduced by almost half. At depths of about 5 meters, the average phytoplankton biomass is just over $30 \%$ of that recorded at the upper level.

Over the entire observation period, including active vegetation and relative rest in the cold season, the average values of biomass of lower plant organisms in the water column varied from 1.17 to $18.2 \mathrm{~g} / \mathrm{m}^{3}$.

Zooplankton. The zooplankton of the reservoir is represented by three planktonic groups of organisms: oar-footed crustaceans (Copepoda), branched crustaceans (Cladocera) and rotifers (Rotatoria).

In addition to typical planktonic forms, larvae of bugs of the genus Corixa, mosquitoes of the family Chironomidae, larvae of beetles of the genus Dytiscus, representatives of the subclass Oligochaeta, class Ostracoda and type Nematoda were found in significant numbers in zooplankton. Observations of the seasonal dynamics of zooplankton in the period from April to September showed that it is characterized by a pronounced periodicity.

In spring, the reservoir maintains a river regime, which is why rotifers (Rotatoria) predominate in the zooplankton (115 thousand ex/ $\mathrm{m}^{3}$ ), accounting for $85 \%$ of the total number of organisms; the average zooplankton biomass during this period is low -0.59 $\mathrm{g} / \mathrm{m}^{3}$, with fluctuations from 0.20 to $1.27 \mathrm{~g} / \mathrm{m}^{3}$.

In the summer, when the water temperature increases, there are significant changes in the development of zooplankton in quantitative and qualitative terms: rotifers (Rotatoria) are significantly inferior to lower crustaceans (Entomostraca). Values are averages of biomass of zooplankton in reservoirs in spring and summer hesitate from $0.88 \mathrm{~g} / \mathrm{cm}^{3}$ to 1.58 $\mathrm{g} / \mathrm{m}^{3}$, which is associated with a predominance of larval and copepodite crustaceans in summer. The highest values of zooplankton biomass in the reservoir were observed in the autumn period (up to $2.85 \mathrm{~g} / \mathrm{m}^{3}$ ).

Significant changes in the development of zooplankton occur both by season and in different parts of the reservoir. So, in the river section, where the strongest currents and a large number of suspensions were observed, zooplankton had the lowest biomass indicators during the entire growing season. Only in summer, with a decrease in the flow rate, it reaches a maximum of development-2.36-3.98 $\mathrm{g} / \mathrm{m}^{3}$.

The zooplankton biomass in the upper section is also small: in the spring 0.14-0.97 $\mathrm{g} /$ $\mathrm{m}^{3}$, in the summer-up to $1.31 \mathrm{~g} / \mathrm{m}^{3}$; rotifers and oar-legged crustaceans predominate. In autumn, this section of the reservoir is drained and filled again only in April-March.

In the Central section of the reservoir, zooplankton biomass varies slightly from 1.95 to $2.45 \mathrm{~g} / \mathrm{m}^{3}$.

Zooplankton biomass ranges from 0.16 to $8.18 \mathrm{~g} / \mathrm{m}^{3}$ in the near-dam section.

Zoobenthos. Seven groups of organisms were observed in the zoobenthos of the reservoir. Most often there are larvae of chironomids (Chironomidae), representatives of the subclass of small - bodied worms (Oligochaeta), single-larvae of beetles (Dytiscus), ruches (Trichoptera), and mysida (Mysida).

The bottom fauna is formed mainly by larvae of chironomids (Chironomidae) - $47 \%$ and Oligochaeta $-42 \%$ (by biomass).

The lowest numbers and biomass of zoobenthos were found in former riverbeds, deep 
areas along the dam, and in the Central zone.

The greatest number and biomass of bottom fauna during the entire growing season are observed in shallow areas of the left Bank of the reservoir with sparse shrubby thickets and coastal aquatic vegetation; the fauna was represented mainly by Oligochaeta, detritus-eating and predatory larvae of chironomids (Chironomidae).

The macrophytes. After filling the reservoir, there was a gradual development of higher aquatic vegetation, currently the species composition is represented by 14 taxa. Most often, sparse groups of air-water species are common in the reservoir: amphibian buckwheat (Polygonum amphibium), common reed (Phragmítes Australis), narrow-leaved cattail (Turcha angustifolia), lake reed (Schoenoplectus lacustris). Less common were submerged plants: rdesta brilliant (Potamogeton lucens), pronzennolistny (P. perfoliatus) and curly (P. crispus), dark-green hornwort (Ceratophullum demersum), and earwort (Myriophullum spicatum).

Macrophytes in the reservoir is currently concentrated in the coastal shallow areas, they are significantly developed at the mouths of the rivers Psekups and Pshish. Amphibian buckwheat (Polygonum amphibium) forms the largest areas of overgrowth in the reservoir and is distributed to a depth of 6 m.previously existing associations of Phragmítes Australis, Bolboschoenus sp. both the angustifolia Turkha are in a depressed state due to a significant increase in the water level.

Thus, forage organisms of the Krasnodar reservoir develop relatively well. Phytoplankton is represented by 206 species and intraspecific taxa of algae belonging to 7 divisions: blue-green (Cyanobacteria), pyrophyta (pyrrophyta), Golden (Chrysophyta), diatomeae (Diatomeae), yellow-green (Xanthophyta), euglenoidea (Euglenoidea) and green (Chlorophyta).

Zooplankton is represented by rotifers (Rotatoria), oar-footed (Copepoda) and branchbill (Cladocera) crustaceans. There are 49 species and subspecies of zooplankton organisms.

The zoobenthos includes representatives of the 5 groups of benthic organisms. The species composition of zoobenthos includes 31 species.

The phytoplankton biomass of the Krasnodar reservoir ranges from 12.35 to $44.15 \mathrm{~g} /$ $\mathrm{m}^{3}$, averaging $15.8 \mathrm{~g} / \mathrm{m}^{3}$, zooplankton biomass - from 2.84 to $9.35 \mathrm{~g} / \mathrm{m}^{3}$, averaging $4.52 \mathrm{~g}$ $/ \mathrm{m}^{3}$, zoobenthos biomass - from 1.5 to $6.7 \mathrm{~g} / \mathrm{m}^{2}$, averaging $2.86 \mathrm{~g} / \mathrm{m}^{2}$.

\section{Kryukov reservoir}

Feed resources (phytoplankton, zooplankton, zoobenthos) of the Kryukov reservoir are developing well. Thus, the phytoplankton biomass varies in the spring period from 0.83 to $4.86 \mathrm{mg} / 1$ (the summer phytoplankton biomass reaches $26.3 \mathrm{~g} / \mathrm{m}^{3}$ ). The average for the growing season is $18.6 \mathrm{~g} / 1^{3}$.

Zooplankton are mainly represented by rotifers (Rotatoria), branchbills (Cladocera), and oar-footed crustaceans (Copepoda). Its population ranges from 7 to 318 thousand ex / $\mathrm{m} 3$, and its biomass is $0.5-5.9 \mathrm{~g} / \mathrm{m}^{3}$. Zoobenthos is mainly represented by larvae of chironomids (Chironomidae) with a biomass of $0.2-3.2 \mathrm{~g} / \mathrm{m}^{2}$. The maximum biomass was noted in may-3.2 $\mathrm{g} / \mathrm{m}^{2}$.

\section{Varnavinsky reservoir}

Feed resources (phytoplankton, zooplankton and zoobenthos) of the Varnavinsky reservoir are developing satisfactorily.

Phytoplankton is represented by 112 taxa belonging to 9 groups. The most diverse in 
taxonomic terms are protococcal algae (Protococcophyceae) - 49 species. An equal number of 15 species were represented by blue-green (Cyanobacteria) and diatomaceous (Diatomeae). Relatively less diversity was characterized by Volvocaceae (Volvocaceae) 8 species, desmidiales (Desmidiales) - 6 species, euglenoidea (Euglenoidea) - 11 species and pyrophyta (Pyrrophyta) - 4 species. The minimum number of 2 species was represented by yellow-green (Xanthophyta) and Golden (Chrysophyta) algae.

Phytoplankton biomass ranges from 0.88 to $4.86 \mathrm{~g} / \mathrm{m}^{3}$ in spring, and summer phytoplankton biomass reaches $24.8 \mathrm{~g} / \mathrm{m}^{3}$. On average, during the growing season, the biomass of phytoplankton in the Varnavinsky reservoir is $13.9 \mathrm{~g} / \mathrm{m}^{3}$.

The zooplankton of the reservoir is represented by three typical planktonic groups of organisms: oar-footed (Copepoda) and branch-billed (Cladocera) crustaceans and rotifers (Rotatoria).

The dynamics of zooplankton biomass for the entire growing season (April-October) has the form of a curve with two vertices. The maximum values of zooplankton biomass in the reservoir were recorded in the spring period (April-may) and ranged from 3.8 to $5.6 \mathrm{~g} /$ $\mathrm{m}^{3}$. In the summer, with the establishment of high water temperatures, there is a sharp decline $\left(0.5-0.8 \mathrm{~g} / \mathrm{m}^{3}\right)$, which is due to the biological characteristics of some species of branched crustaceans (Cladocera). By mid-September, when the water temperature approaches optimal values and the gas composition is normalized, the zooplankton biomass begins to grow again, reaching $1.6 \mathrm{~g} / \mathrm{m}^{3}$. Thus, during the growing season, changes occur in the dominant number and biomass of taxa, in this connection, the number of zooplankton organisms ranges from 12 to 320 thousand copies $/ \mathrm{m} 3$, and their biomass - from 0.5 to $5.6 \mathrm{~g}$ $/ \mathrm{m}^{3}$, making an average for the observation period $-2.3 \mathrm{~g} / \mathrm{m}^{3}$.

Zoobenthos. Organisms representing the EPI-and infauna of the bottom communities of the reservoir belong to the following groups of organisms: chironomid larvae (Chironomidae), Oligochaeta (Oligochaeta), beetle larvae (Dytiscus), mysida (Mysida), Gammaridae (Gammaridae)). The larvae of chironomids (Chironomidae) dominate, the biomass of which varied from 0.4 to $3.5 \mathrm{~g} / \mathrm{m}^{2}$ during different observation periods. On average, during the growing season, the total biomass of invertebrate organisms inhabiting benthic communities is $1.89 \mathrm{~g} / \mathrm{m}^{2}$.

According to the level of development of forage organisms, the Kryukov and Varnavinsky reservoirs are medium-sized reservoirs.

\section{Ichthyofauna of reservoirs in the Kuban basin}

\subsection{Krasnodar reservoir}

The formation of the ichthyofauna of artificial reservoirs of complex purpose has a number of General regularities. The ichthyofauna of the Krasnodar reservoir formed at the expense of fishes that lived before in Texcom reservoir, fish the middle and lower reaches of the river Kuban and its left-Bank tributaries: the rivers Laba, Belaya, Pshish, Psekups, etc. Various sources note the great diversity of the fish fauna of the basin of the Kuban river, with more than 79 species and subspecies of fish, of which 36 are constantly encountered in the reservoir, and 43 species and subspecies occur sporadically at different times of the year $[5,6,7]$. They include marine, pass-through and semi-passable fish (Beluga (Huso huso), sevruga (Acipenser stellatus), russian sturgeon (Acipenser gueldenstaedti), black sea shad (Alosa maeotica), black sea sprat (sprat) (Clupeonella cultriventris), three-legged stickleback (Gasterosteus aculeatus), and Common percarina (Percarina demidoffi), donets ruffe (Gymnocephalus acerinus), European anchovy (Engraulis encrasicholus) and some types of gobies), which found favorable conditions for reproduction both in the reservoir 
bowl and in the rivers that flow into it, as well as some universes - sturgeon (Acipenser ruthenus), american paddlefish (Polyodon spathula), smallmouth buffalo (Ictiobus bubalus), grass carp (Ctenopharyngodon idella), black carp (Mylopharyngodon piceus), channel catfish (Ictalurus punctatus), silver carp (Hypophthalmichthys molitrix) and bighead carp (Hypophthalmichthys nobilis).

Of these fish, no beluga (Huso huso), Russian sturgeon (Acipenser gueldenstaedti), American paddlefish (Polyodon spathula), black buffalo (Ictiobus niger) and smallmouth buffalo (Ictiobus bubalus), black carp (Mylopharyngodon piceus), So-iuy mullet (Liza haematocheila), grass carp (Ctenopharyngodon idella), bigmouth buffalo (Ictiobus cyprinellus), and some species of goby. At the same time, Volga pikeperch (Sander volgensis), previously noted as an isolated occurrence, is now numerous and serves as a fishing object. Our research on the Krasnodar reservoir and the rivers that flow into it showed that the ichthyofauna is represented by 6 complexes. The most widely represented Pontic freshwater complex, which includes 16 species and subspecies of fish: vyrezub (Rutilus frisii frisii), common rudd (Scardinius erythrophthalmus), kuban podust (Chondrostoma colchicum kubanicum), common bleak (Alburnus alburnus), bream (Abramis brama), sabre carp (Pelecus cultratus), Crimean barbel (Barbus tauricus kubanicus), three-legged stickleback (Gasterosteus aculeatus), Danube bleak (Chalcalburnus chalcoides schischkovi), white-eye bream (Ballerus sapa), asp (Aspius aspius), belica (Leucaspius delineatus), Transcaucasian spirlin (Alburnoides fasciatus), Blicca bjoerkna (Blicca bjoerkna), vimba (Vimba vimba), Ukrainian stickleback (Pungitius platygaster)). Other complexes include from 3 to 10 types. So, drevneverkhnetretichny - 6 species: sterlet (Acipenser ruthenus), sevruga (Acipenser stellatus), zander (Sander lucioperca), Volga pikeperch (Sander volgensis), carp (Cyprinus carpio), wels catfish (Silurus glanis), boreal plain-10 species: pike (Esox lucius), crucian carp (Carassius carassius), Gibel carp (Carassius auratus), European perch (Perca fluviatilis), roach (Rutilus rutilus), tench (Tinca tinca), gobio gobio (Gobio gobio), ruffe (Gymnocephalus cernuus), spined loach (Cobitis taenia), Caucasian spiny loach (Sabanejewia caucasica)), boreal foothill - 7 species: Stone loach (Barbatula barbatula), Krynicki's loach (Barbatula merga), common Chub (Squalius cephalus), Caucasian Chub (Squalius cephalus orientalis), Dnieper chub (Squalius borysthenicus), Aphips chub (Squalius aphipsi), Eurasian minnow (Phoxinus phoxinus), Pontic sea - 9 species: Black sea shad (Alosa maeotica), Azov shad (Alosa caspia tanaica), Black Sea sprat (Clupeonella Cultriventris), straightnose pipefish (Nerophis ophidion), Black-striped pipefish (Syngnathus nigrolineatus), grass goby (Gobius ophiocephalus), three species of the genus Neogobius), Chinese plain - 3 species: grass carp (Ctenopharyngodon idella), white silver carp (Hypophthalmichthys molitrix) and variegated bighead carp (Hypophthalmichthys nobilis).

According to the nature of reproduction, the ichthyofauna of the Krasnodar reservoir is divided into 5 ecological groups. The most widely represented phytophilic ecological group includes 17 species and subspecies of fish. Lithophilic ecological group - 6 species, psammophilic-8 species, pelagophilic-4 species, gestating- 2 species of fish.

According to the terms of spawning, the main part of the fish species of the Krasnodar reservoir belongs to the spring-spawning and spring-summer ones. However, the timing of fish spawning in the Krasnodar reservoir is not constant and depends on spawning temperatures and water level regime. Almost every year, due to a sharp discharge of water on the farm, the beginning spawning course of fish to spawning grounds is interrupted three times, and sometimes the spawning of fish. In this regard, the spawning efficiency of the main commercial fish species is extremely low.

The systematization of fish in the Krasnodar reservoir by the nature of food is complicated by the fact that the main part of the species feeds on a variety of forage organisms. It is difficult to identify the dominant food item. The main part of the species is 
peaceful, and only 6 species (Sander lucioperca, Sander volgensis, Perca fluviatilis, Silurus glanis, Esox lucius, Aspius aspius) are predatory. Peaceful fish in the diet are divided into the following groups and subgroups: herbivorous - fitoplanktona (Hypophthalmichthys molitrix), macropelopia (Ctenopharyngodon idella), purificatory (Chondrostoma nasus); animal-eaters - zooplantophages (Chalcalburnus chalcoides schischkovi, Alburnus alburnus, Leucaspius delineatus, Pelecus cultratus, Hypophthalmichthys nobilis), zoobentophages (Cyprinus carpio, Abramis brama, Blicca bjoerkna, etc.); detritos detritophages (Carassius carassius). However, when analyzing the range of fish nutrition in the Krasnodar reservoir, we can trace the multicomponent composition of their food and the existing species composition of fish, which masters almost all the food niches of the reservoir. The basis of the diet of predatory fish is mainly small low-value species.

Thus, the ichthyofauna of the Krasnodar reservoir and rivers flowing into it are represented by 36 species of fish that live permanently and 43 species that come in for spawning or short-term feeding. However, the fishery is based on 5-8 species of fish (Cyprinus carpio, Abramis brama, Sander lucioperca, Pelecus cultratus, Carassius auratus, Blicca bjoerkna, Rutilus rutilus).

\subsection{Kryukov reservoir}

The ichthyofauna of the reservoir is represented by six families (Cyprinidae, Esocidae, Cobitidae, Percidae, Gobiidae, Gasterosteidae). The family Cyprinidae is the most diverse in terms of species, which includes 15 species (Cyprinus carpio, Abramis brama, Rutilus rutilus, Blicca bjoerkna, Aspius aspius, Alburnus alburnus, Scardinius erythrophthalmus, Carassius carassius, Carassius auratus, Tinca tinca, Gobio gobio, Leucaspius delineatus, Hypophthalmichthys molitrix, Hypophthalmichthys Nobilis, ctenopharyngodon idella). The Percidae family includes three species (Sander lucioperca, Perca fluviatilis, Gymnocephalus cernuus), Esocidae-Esox lucius), Cobitidae-also one species of Cobitis taenia, Gobiidae two species (Neogobius melanostomus, Neogobius fluviatilis), Gasterosteidae - one (Pungitius platygaster).

In relation to the spawning substrate, the ichthyofauna of the Kryukov reservoir is represented mainly by phytophilic species - 10 taxa. Exceptions are Gobio gobio (psammophiles), Hypophthalmichthys molitrix, Hypophthalmichthys nobilis, Ctenopharyngodon idella (pelagophiles), Sander lucioperca, Perca fluviatilis (indifferent), Aspius aspius (lithophiles).

The nature of power in the ichthyofauna is represented by 5 groups: fitoplancton, phytophages, zooplanktivore, benthophage and prey, among which the most numerous are zooplanktonic and bentofag.

The formation of the fish fauna occurs mainly in a natural way. This led to the formation of populations of low-value fish species (Scardinius erythrophthalmus, Rutilus rutilus, Perca fluviatilis, Leucaspius delineatus, etc.), which currently occupy the first place in both numbers and ichthyomass. Directed formation of the ichthyofauna of the Kryukovsky reservoir has been going on for a long time, but the introduction of valuable fish species into the reservoir is carried out in insufficient numbers. In addition, the issue of conducting fishery reclamation measures aimed at reducing the number of weedy and lowvalue fish species that act as trophic competitors to commercial species is acute. Valuable fish species (Cyprinus carpio, Abramis brama, Hypophthalmichthys molitrix, Hypophthalmichthys nobilis, Ctenopharyngodon idella, Sander lucioperca, Mylopharyngodon piceus) are characterized by high biological indicators, but their number is insignificant.

\subsection{Varnavinsky reservoir}


The species composition of the ichthyofauna of the Varnavinsky reservoir includes 27 species of fish (Cyprinus carpio, Rutilus rutilus, Abramis brama, Squalius cephalus, Scardinius erythrophthalmus, Aspius aspius, Tinca tinca, Gobio gobio, Leucaspius delineatus, Blicca bjoerkna, Carassius carassius, Carassius auratus, Ctenopharyngodon idella, Hypophthalmichthys molitrix, Hypophthalmichthys Nobilis, Chalcalburnus chalcoides schischkovi, Vimba vimba vimba, Cobitis taenia, sander lucioperca, Perca fluviatilis, gymnocephalus Cernuus, silurus Glanis, Esox Lucius, nerophis ophidion, pungitius Platygaster, Knipowitschia longicaudata, Neogobius fluviatilis).

The process of formation of the ichthyofauna is mostly completed and now the reservoir is inhabited by both representatives of the native ichthyofauna and acclimatisers. The largest number is created by low-value fish species, the number of valuable species is relatively small.

Natural reproduction, due to abiotic factors (reservoir filling and drainage, temperature, weather conditions, etc.), is difficult and its efficiency is low.

The efficiency of natural reproduction depends entirely on the level, temperature, and wind conditions of the reservoir. High water content in the spring period is later replaced by a sharp decrease in incoming water, which leads to limited areas of spawning grounds and feeding of young. Ultimately, this determines the weak efficiency of natural reproduction of phytophiles.

In the most unfavorable environmental conditions, Cyprinus carpio is very sensitive to changes in abiotic factors and the quality of spawning grounds. However, despite the relative plasticity of other fish species (Abramis brama, Rutilus rutilus) in the selection of spawning substrate and spawning sites, high efficiency in their reproduction is not observed. Violation of gradual warming and falling water levels, combined with rainy and windy weather, inhibits the participation of producers in spawning, leads to drying out of spawning grounds and disruption of the reproductive process of females. The resulting generations of fish are very small and a significant increase in commercial stocks, except for Carassius auratus, is not expected.

To increase the efficiency of natural reproduction of valuable fish species, it is necessary to carry out a number of fish-breeding and reclamation measures, which should include the installation of artificial spawning grounds, stocking with valuable fish species, as well as an agreed schedule of water intake for agriculture, taking into account the fisheries.

The fish that live in the Varnavinsky reservoir do not differ significantly in biological data from the fish of the Kryukovsky reservoir. Fish spawning begins at the same time, the terms of maturation of carp, bream, pike perch coincide, the fertility of females of the Varnavinsky reservoir is the same as in Kryukovsky. The range of nutrition and the rate of linear and weight growth of carp, bream, walleye and herbivorous fish in both reservoirs is the same.

Thus, despite the small size of the Varnavinsky reservoir, it is of fishery importance and requires fish-breeding and reclamation activities, since the native ichthyofauna will not be able to provide high fish productivity.

Studies conducted on reservoirs in the Kuban basin have shown that the Krasnodar reservoir is the most rich in species, with 79 taxa. The species composition of the ichthyofauna of the Kryukovsky and Varnavinsky reservoirs includes 23 and 27 species, respectively.

The ichthyofauna of the reservoirs of the Kuban basin (mainly Krasnodar) is constantly replenished with new species from remote ecosystems as a result of fish-breeding and acclimatization works and hydrostructure. To date, there are more than 38 species (Pseudorasbora parva, Rhodeus amarus, Ictalurus punctatus, Ctenopharyngodon idella, Hypophthalmichthys molitrix, Hypophthalmichthys nobilis, Oryzias latipes, Cobitis 
melanoleuca, Neogobius syrman, etc.). It should be noted that the ichthyofauna of the Kuban river basin has been replenished with a significant number of new species, including naturalized due to introductions ( 7 species), self-dispersing ( 5 species) and expanded ranges (18 species).

Along with this, the ichthyofauna of reservoirs in the Kuban basin is represented by a significant number of endemic forms (Chondrostoma colchicum kubanicum, Barbus tauricus kubanicus, Leuciscus aphipsi, Alburnoides kubanicus, Romanogobio pentatrichus, Sabanejewia kubanica, etc.). Thus, the current composition of the ichthyofauna of the reservoirs of the Kuban river basin is represented by 79 species of fish, among which there are both mass ubiquitous and single-occurring tuvodnye, semi-passable, passable, acclimatized and self-acclimatized species [8,9].

Methods for increasing fish productivity of reservoirs of pasture aquaculture in the Kuban basin

Studies have shown that forage resources (phytoplankton, zooplankton, zoobenthos, macrophytes) of reservoirs are developing quite well. The average seasonal biomass of phytoplankton in reservoirs ranges from $13.9 \mathrm{~g} / \mathrm{m}^{3}$ (Varnavinsk reservoir) to $18.6 \mathrm{~g} / \mathrm{m}^{3}$ (Kryukov reservoir), zooplankton from $2.3 \mathrm{~g} / \mathrm{m}^{3}$ (Varnavinsk reservoir to $4.52 \mathrm{~g} / \mathrm{m}^{3}$ (Krasnodar reservoir), zoobenthos from $1.89 \mathrm{~g} / \mathrm{m}^{2}$ (Varnavinsk reservoir) to $2.86 \mathrm{~g} / \mathrm{m}^{2}$ (Krasnodar reservoir). However, feed organisms mainly use low-value, low-growth fish species that produce low-quality fish products. Phytoplankton and macrophytes are hardly used by local fish species.

Climatic conditions cause a high bio-production capacity of reservoirs in the southern region. However, without carrying out work on constructive regulation of the species composition and number of individual fish species in reservoirs, their actual fish productivity becomes significantly lower than the potential [10-16]. When determining the potential fish productivity of pasture aquaculture reservoirs, we used the following $\mathrm{P} / \mathrm{V}$ coefficients for more reliable calculations: for phytoplankton -45 , for zooplankton -15 , for zoobenthos -6 , for macrophytes -1.1 . The obtained data on the production of phytoplankton, zooplankton, zoobenthos and macrophytes are indicative, but they can be used to directly determine the potential fish productivity of reservoirs (table.1).

Table 1. Potential fish productivity of reservoirs in the Kuban basin.

\begin{tabular}{|c|c|c|c|c|c|c|}
\hline \multirow[t]{2}{*}{$\underset{\text { organisms' }}{\text { Group }}$} & $\begin{array}{l}\text { Residual } \\
\text { biomass. } \\
\text { kg / ha }\end{array}$ & \multirow[t]{2}{*}{$\begin{array}{c}\text { P / B - } \\
\text { coefficie } \\
\text { nt }\end{array}$} & $\begin{array}{l}\text { Production. } \\
\text { kg / ha }\end{array}$ & \multirow[t]{2}{*}{$\begin{array}{c}\text { Use of } \\
\text { products. } \\
\%\end{array}$} & \multirow[t]{2}{*}{$\begin{array}{l}\text { Feed } \\
\text { ratio }\end{array}$} & \multirow{2}{*}{\begin{tabular}{|c|}
$\begin{array}{c}\text { Potential } \\
\text { fish } \\
\text { production. } \\
\text { kg / ha }\end{array}$ \\
$\mathbf{M} \pm \mathbf{m}$ \\
\end{tabular}} \\
\hline & $\mathbf{M} \pm \mathbf{m}$ & & $\mathbf{M} \pm \mathbf{m}$ & & & \\
\hline \multicolumn{7}{|c|}{ Krasnodar reservoir } \\
\hline Phytoplankton & $127.4 \pm 1.06$ & 45 & $5733.0 \pm 1.21$ & 50 & 30 & $95.5 \pm 1.75$ \\
\hline Zooplankton & $83.6 \pm 1.56$ & 15 & $1254.0 \pm 1.16$ & 60 & 10 & $75.2 \pm 1.36$ \\
\hline Zoobenthos & $69.8 \pm 0.79$ & 6 & $418.8 \pm 1.55$ & 50 & 6 & $34.9 \pm 1.45$ \\
\hline Macrophytes & $2625 \pm 2.71$ & 1.1 & $2887.5 \pm 2.78$ & 15 & 50 & $8.7 \pm 2.24$ \\
\hline Total: & & & & & & 214.3 \\
\hline \multicolumn{7}{|c|}{ Kryukov reservoir } \\
\hline Phytoplankton & $116.7 \pm 2.74$ & 45 & $5251.5 \pm 1.76$ & 50 & 30 & $87.5 \pm 2.46$ \\
\hline Zooplankton & $42.4 \pm 1.34$ & 15 & $1048.4 \pm 2.16$ & 60 & 10 & $38.2 \pm 1.65$ \\
\hline Zoobenthos & $32.8 \pm 0.89$ & 6 & $196.8 \pm 1.32$ & 50 & 6 & $16.4 \pm 0.69$ \\
\hline Macrophytes & $13056 \pm 6.4$ & 1.1 & $47361.6 \pm 3.65$ & 15 & 50 & $43.1 \pm 1.45$ \\
\hline
\end{tabular}




\begin{tabular}{|l|c|c|c|c|c|c|}
\hline \multicolumn{7}{|l|}{ Total: } \\
\hline \multicolumn{7}{|c|}{ Varnavinsky reservoir } \\
\hline Phytoplankton & $132.4 \pm 1.07$ & 45 & $5958.0 \pm 1.09$ & 50 & 30 & $99.3 \pm 1.54$ \\
\hline Zooplankton & $41.4 \pm 2.53$ & 15 & $621.0 \pm 1.42$ & 60 & 10 & $37.3 \pm 1.47$ \\
\hline Zoobenthos & $36.9 \pm 0.95$ & 6 & $221.4 \pm 1.96$ & 50 & 6 & $18.5 \pm 1.23$ \\
\hline Macrophytes & $16132 \pm 1.8$ & 1.1 & $17745.2 \pm 1.56$ & 15 & 50 & $53.2 \pm 1.32$ \\
\hline Total: & & & & 208.3 \\
\hline
\end{tabular}

In order to achieve the calculated indicators of fish productivity of reservoirs in the Kuban basin, it is necessary to carry out a set of reclamation works to reduce the number of low-value and predatory fish species. The basis of commercial ichthyofauna should be valuable fast-growing species. In this regard, to ensure the achievement of the planned indicators of the commercial yield of fish stocking of reservoirs is advantageously carried out with fingerlings (Ctenopharyngodon idella, Hypophthalmichthys molitrix, Hypophthalmichthys nobilis) and extension: Cyprinus carpio, Mylopharyngodon piceus, Liza haematocheila, etc.) individual weight below 25-30 g, at the rate of $250 \mathrm{ind} / \mathrm{ha}$ white silver carp, $100 \mathrm{ind} / \mathrm{ha}$ bighead carp, and 50 ind./ha grass carp, 30 ind./ha carp-carp. In the third year after stocking, when the fish reach an individual weight of $2.0-2.5 \mathrm{~kg}$ and when leaving the fish landing $15-25 \%$, the fish productivity of the Krasnodar reservoir will be $195 \mathrm{~kg} / \mathrm{ha}$, the Kryukovsky reservoir - $168 \mathrm{~kg} / \mathrm{ha}$, and the Varnavinsky reservoir-192 $\mathrm{kg} /$ ha.in addition, local fish can give up to $5 \mathrm{~kg} / \mathrm{ha}$ of fish products. In total, the fish productivity of reservoirs can reach about $200 \mathrm{~kg} / \mathrm{ha}$. Currently, the catch is based on lowvalue fish species (Carassius auratus, Pelecus cultratus, Blicca bjoerkna, Rutilus rutilus, Scardinius erythrophthalmus, etc.), the fish productivity is $2-5 \mathrm{~kg} / \mathrm{ha}$.

Thus, the reservoirs of the Kuban basin are quite suitable for growing commercial fish by pasture type. When conducting fish-breeding and reclamation works on reservoirs and stocking them with valuable fast-growing fish species, the fish productivity can reach 170$200 \mathrm{~kg} / \mathrm{ha}$.

\section{References}

1. A.V. Abramchuk, G.A. Moskul, N.G. Pashinova, Natural and technical Sciences 10(124), $75-77$ (2018)

2. G.I. Karnaukhov, A.S. Zlotnikov, Biological diversity: study, conservation, restoration, rational use: materials of the scientific and practical International conference (Kerch, Arial, 2018)

3. O. Bilous, S. Barinova, N. Ivanova, O. Huliaieva, Ecohydrology \& Hydrobiology 3, 160-174 (2016)

4. Huai-dong Zhou, Cui-ling Jiang, Li-qin Zhu, Xin-wei Wang, Xiao-qin Hu, Jun-yu Cheng, Ming-hua Xie, Water Science and Engineering 1, 92-100 (2011)

5. G.I. Karnaukhov, State and prospects of scientific and technological development of the fishery complex: materials of the National scientific and practical conference (Makhachkala, 2019)

6. A.V. Abramchuk, N.G. Pashinova, G.A. Moskul, Fish industry 5, 64-67 (2018)

7. G.I. Karnaukhov, Biological diversity: study, conservation, restoration, rational use: materials of the scientific and practical International conference (Kerch, Arial, 2018) 
8. M.S. Chebanov, E.V. Galich, Y.G. Merkulov, V. Bekbergenova, V.N. Krupsky, Materials of the all-Russian scientific and practical conference dedicated to the 20th anniversary of the opening of the "Water bioresources and aquaculture" (Kuban state University, Krasnodar, 2018)

9. V. Golovanov, A. Litvinov, Fish farming and fisheries 4, 17-23 (2014)

10. G.G. Matishov, E.N. Ponomareva, M.N. Sorokina, International youth scientific conference "Oceanography in the XXI century: current facts, models, methods and tools" (UNC RAS, Rostov n/D, 2017)

11. Ya. Sklyarov, State and prospects of development of freshwater aquaculture: materials of the scientific and practical International conference (RSAU-MAA named after. K.

A. Timiryazeva, Moscow, 2013)

12. L. Kalinina, I. Zelenskaya, SHS Web of Conferences 55, 01008 (2018)

13. D.A. Vekhov, A.N. Naumenko, V.P. Gorelov, T.B. Golokolenova, Fisheries research on water bodies in the European part of Russia, 116-145 (2014)

14. G. Moskul, A.V. Abramchuk, N.G. Pashinova, Scientific research of the SCO countries: synergy and integration (Beijing, 2019)

15. O. Fedonenko, N. Esipova, O. Marenkov, Bulletin of fisheries science 2, 61-65 (2014) 